\title{
Mickey Dewar: Memories, books and museums
}

\section{David Carment}

Mickey Dewar's contributions to the history of her beloved Northern Territory were immense. She was an elegant and original writer, a careful researcher with a knack for discovering elusive sources, the energetic member of numerous heritage and history boards and committees, a mentor for other historians and history students, an interesting and always thoroughly prepared school and tertiary teacher, a much sought after public speaker, the Territory's most innovative history curator and an always helpful librarian. She was also sparkling company and probably the most rapid reader I have ever known. Like many others, I learned a lot from her. I do not in this paper attempt to cover all the numerous aspects of her life as a historian. Instead, I recount some of my own memories of Mickey before discussing examples of her sole-authored books and curatorial work.

\section{Memories}

I first met Mickey in Darwin during 1984. I was on the Northern Territory Literary Awards committee and she was a prize winner in the short story section. Her entry was a beautifully composed and very funny account of schoolteachers in Arnhem Land. She commented to me at the prizegiving ceremony that she was also a historian and was writing a Master's thesis at the University of New England about missionary contact with the Yolngu people of north-east Arnhem Land. ${ }^{1}$ A version of it was later

1 Dewar, 'Strange Bedfellows'. 
published as a book. ${ }^{2}$ As she later recounted, her discussions from 1979 onwards with her friends the Northern Territory historians Ann McGrath and Alan Powell and reading Alan's Far Country: A Short History of the Northern Territory ${ }^{3}$ had already led her to discover that the Territory was 'a very exciting place'. Researching and writing about its past 'really was terrific fun'. ${ }^{4}$

I saw her sporadically over the next several years while she was working with the Territory's Department of Education, looking after two young children and finishing the thesis, which I enjoyed discussing with her. It was during these discussions that she expressed interest in embarking on a $\mathrm{PhD}$ thesis dealing with ways in which Australian writers viewed the Northern Territory. In particular she wanted to examine how the Territory was depicted as the region in which the Australian outback tradition was most powerfully idealised. The topic excited me and in due course Alan Powell and I were her joint supervisors at the University College of the Northern Territory and, from 1989, Northern Territory University. I greatly enjoyed reading Mickey's drafts. They were well organised and full of interesting material and perceptive ideas. Little supervision was required but I looked forward to our regular meetings. She was highly efficient, finishing the thesis on time. ${ }^{5}$ Not surprisingly, the three examiners, Brian de Garis, Christine Doran and David Walker, commented positively. The thesis later formed the basis of her prizewinning book In Search of the Never-Never: Looking for Australia in Northern Territory Writing, which appeared in $1997 .{ }^{6}$ She kindly asked me to launch it during a Museums Australia conference in Darwin she had helped organise. During her $\mathrm{PhD}$ candidature Mickey also took tutorials in the first-year subject on Australian history that I taught. I received much unsolicited favourable feedback from her students. She worked hard as a member of the organising committee for the 1991 Australian Historical Association conference in Darwin.

2 Dewar, The 'Black War' in Arnhem Land.

3 Powell, Far Country.

4 Dewar, 'Thoughts on Emeritus Professor Alan Powell', 2.

5 Dewar, 'In Search of the "Never-Never".

6 Dewar, In Search of the Never-Never. 


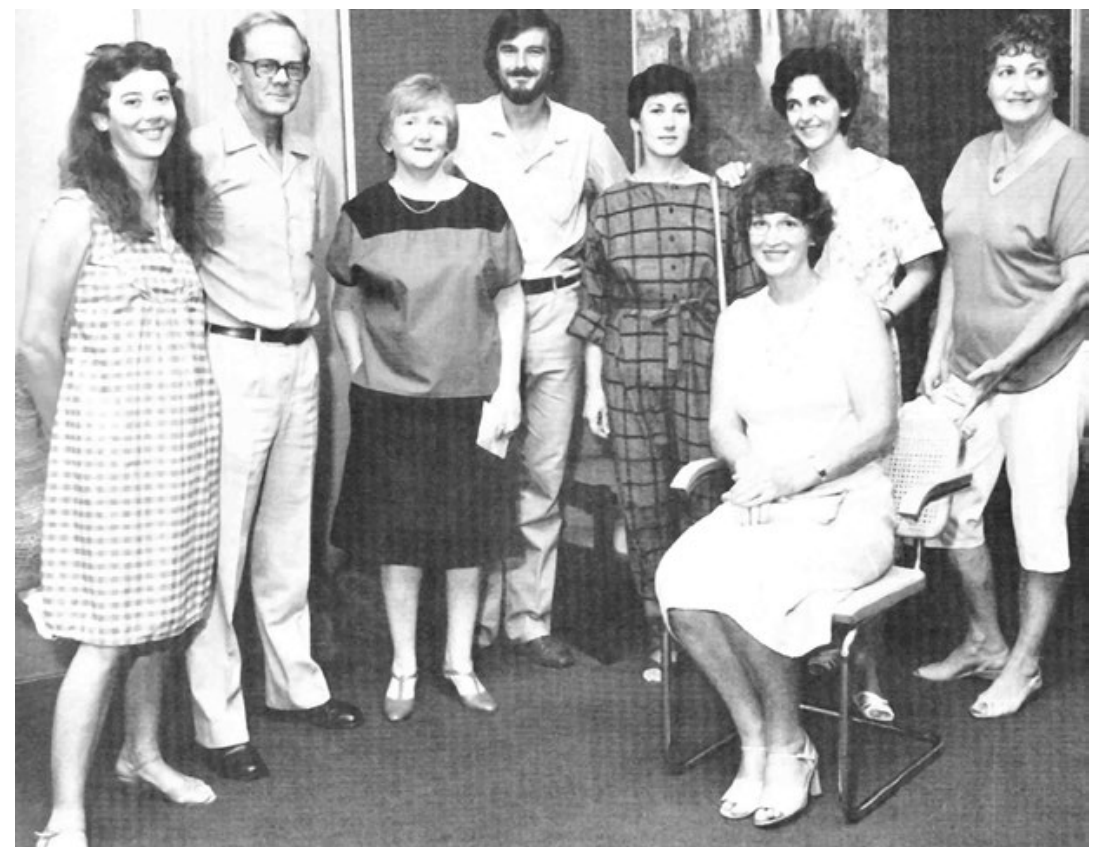

Figure 1: Northern Territory prize winners in the 1984 Northern Territory Literary Awards. Left to right are Mickey Dewar, Graham Calley, Peggie Kerr, David Headon (Chairman of Awards), Connie Gregory, Vivienne Jennings (seated), Kate Veitch and Kathleen Reardon.

Source: Connie Gregory.

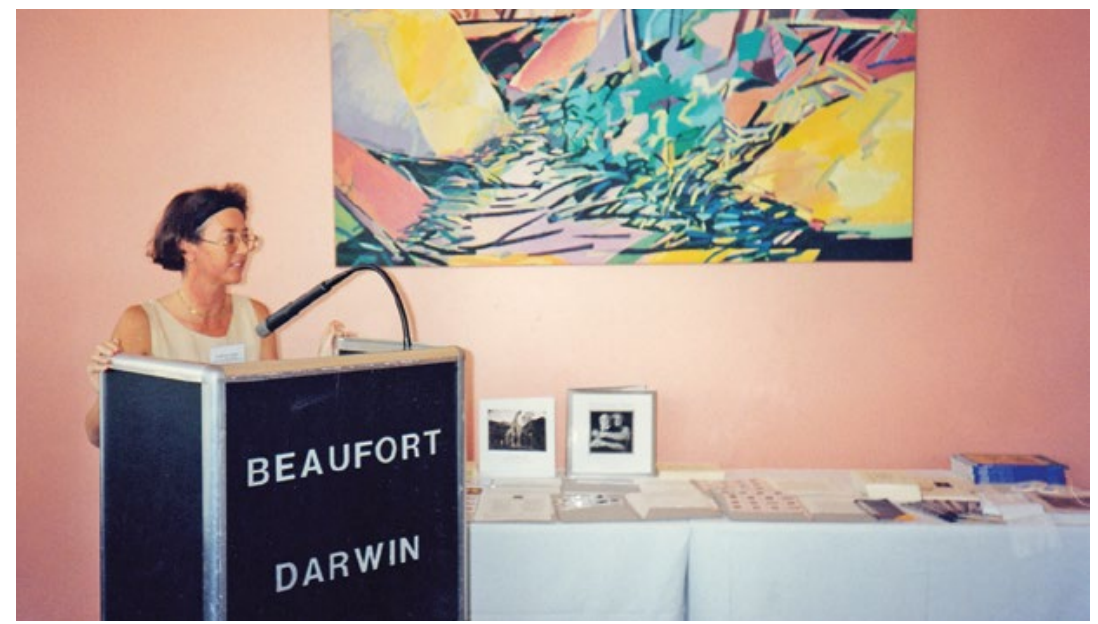

Figure 2: Mickey Dewar at the Darwin launch of In Search of the Never-Never: Looking for Australia in Northern Territory Writing in 1997.

Source: David Carment. 
We remained in frequent contact during the period Mickey was curator and senior curator of Territory History at the Museum and Art Gallery of the Northern Territory (MAGNT, sometimes also officially referred to as Museums and Art Galleries of the Northern Territory) with breaks for a postdoctoral fellowship at Northern Territory University from 1995 to 1996 and to work as adviser and senior adviser to her friend the Territory Chief Minister Clare Martin between 2002 and 2005. We jointly authored a paper on Darwin as an Asian capital for the 1994 Australian Historical Association conference in Perth. ${ }^{8}$ It was delightful to have her as a colleague between 1995 and 1996 when she used her postdoctoral fellowship to write a well-received and much referred to book on the social history of Darwin's Fannie Bay Gaol. ${ }^{9}$ I took a close interest in her curatorial initiatives, about which I say more later, and a couple of my honours students did internships with her. During 2002, together with Margaret Anderson we debated museum history in Australian Historical Studies articles. ${ }^{10}$ With Kathy De La Rue and Clayton Fredericksen, I contributed a chapter to the 2005 book Mickey coedited with Julie Wells and Suzanne Parry on the Northern Territory during the 1950s. ${ }^{11}$ Mickey's own typically innovative chapter was entitled 'You Are What You Eat: Food and Cultural Identity'. ${ }^{12}$ Also in 2005 she and her husband David Ritchie, with whom she shared historical interests, participated in a field trip that my colleague Kate Senior and I organised to the remote Roper River district. Their enthusiasm and knowledge contributed to the trip's success. A site we visited with the traditional owners' permission was a large cave filled with detailed rock art that David previously documented when he worked for the Aboriginal Areas Protection Authority.

7 Dewar, Resumé, 3.

8 Carment and Dewar, 'Darwin: Australia's Asian Capital?'.

9 Dewar, Inside-Out.

10 Anderson, 'Oh What a Tangled Web...'; Carment, 'Making Museum History in Australia's Northern Territory'; Dewar, 'If I Was Writing My Own History I'd Be a Hero'.

11 Carment, Fredericksen and De La Rue, 'From "Native Relics" to "Flynn's Pillar".

12 Dewar, 'You Are What You Eat'. 


\section{Modern Frontier:}

\section{Aspects of the 1950s}

in Australia's Northern Territory

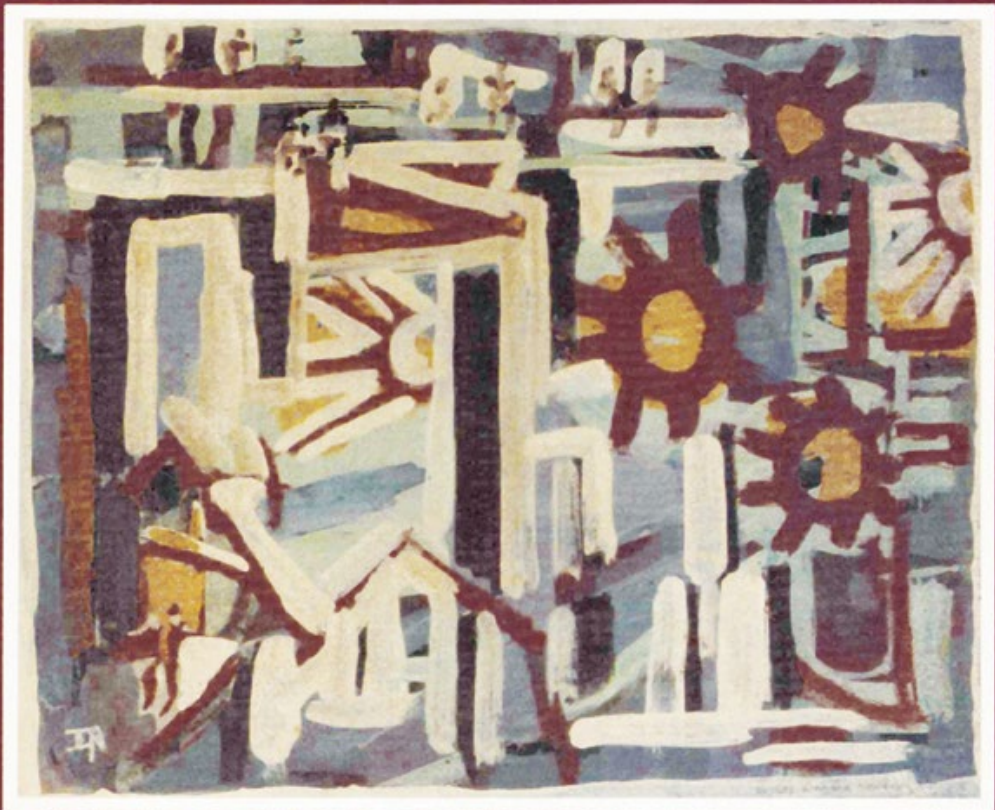

Editors

Julie T Wells, Mickey Dewar, Suzanne Parry

Figure 3: Julie T. Wells, Mickey Dewar and Suzanne Parry (eds), Modern Frontier: Aspects of the 1950s in Australia's Northern Territory (Darwin: Charles Darwin University Press, 2005).

Source: Suzanne Parry, David Ritchie, Peter Quinn and (c) lan Fairweather/DACS.

Copyright Agency. 


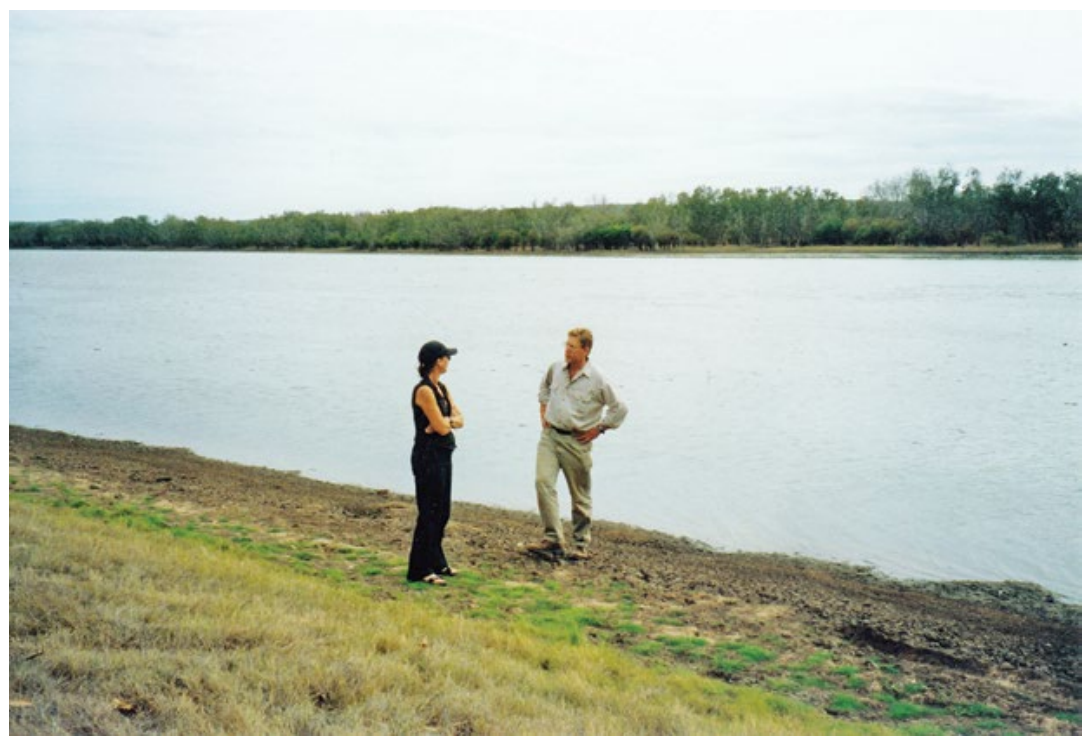

Figure 4: Mickey Dewar with David Ritchie at the Roper River in 2005.

Source: David Carment.

I saw Mickey a bit less often following my retirement and permanent move to Sydney in 2008, but we kept in contact and quite often caught up for breakfast, sometimes with David joining us, at the Fannie Bay Cool Spot when I visited Darwin. Her productivity and undisguised joy while a researcher, consultant and librarian ${ }^{13}$ continued to impress me. At Darwin's annual History Colloquium in 2010, I launched her book on 1950s housing history. ${ }^{14}$ Two years later, I enjoyed reading the book she compiled with Clare Martin in which eight Territory chief ministers reflected on self-government. ${ }^{15}$ I often called on her for Northern Territory Historical Studies (formerly the Journal of Northern Territory History) book reviews. She very rarely said no and her polished reviews were always submitted before their deadlines and the correct length.

13 Dewar, Resumé, 3.

14 Dewar, Darwin - No Place Like Home.

15 Martin and Dewar, Speak for Yourself. 


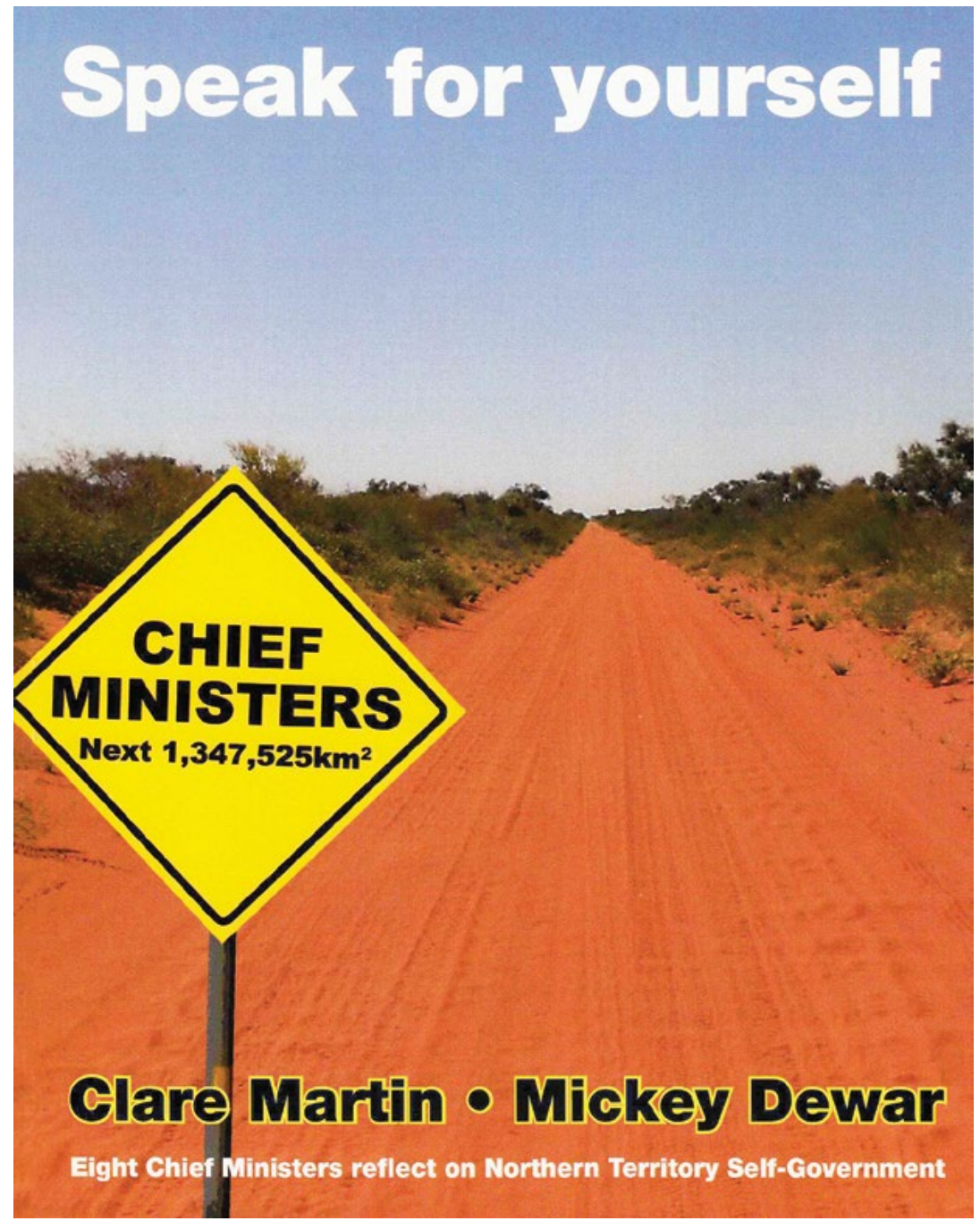

Figure 5: Clare Martin and Mickey Dewar (comps), Speak for Yourself: Eight Chief Ministers Reflect on Northern Territory Self-Government (Darwin: Charles Darwin University Press, 2012).

Source: Clare Martin, Chips Mackinolty and David Ritchie. 
She especially revelled in her final job, which she shared with her close friend Sam Wells, as heritage coordinator at the Northern Territory Library. Among other things, it allowed her to return to curatorship. It also permitted her and David to spend a quite long period each year at their holiday home in Aireys Inlet, Victoria, where they enjoyed the spectacular rugged scenery and the swimming. I spent a memorable day with them there in October 2015. Many of our most recent communications concerned the symposium at the Northern Territory Library in May 2017 to honour Alan Powell that Sam and Mickey organised and I chaired. Mickey had invited me to stay with her and David while I was in Darwin for the event, but I received an email from her in early February advising that:

I am afraid I am writing as such a fair weather friend. I invited you to stay with us at Alan's symposium in May but the truth is I have to rescind the offer because I won't be there.

This time I was south I was diagnosed with a fairly serious illness. Still having tests etc. but I am afraid it will be serious and I am unlikely to make it back to Darwin any time soon. I'm sorry I can't have you to stay in our lovely new house and I'm disappointed that I am not going back to work as per usual on 1 April. And, well, a whole lot of other things too as you might imagine but not to be boring here. ${ }^{16}$

She added that the illness resulted in her being unable to speak. 'Silence', she wrote, 'is a bit of a change for me as you might imagine!' ${ }^{17}$ Shortly afterwards she disclosed that she had motor neurone disease. In spite of all that, before her death on 23 April she wrote a wonderfully warm paper for the symposium that Sam presented for her. 'I wish', she wrote, 'I could be there with you Alan, to celebrate today: an esteemed colleague, a great writer, premier historian, and good friend - make sure you have a drink - or two, for me'. ${ }^{18}$ While, as Mickey would have wished, the symposium was mainly about Alan, several speakers also warmly acknowledged her achievements and friendship.

16 Dewar, email to David Carment, 10 February 2017.

17 Dewar, email to David Carment, 10 February 2017.

18 Dewar, 'Thoughts on Emeritus Professor Alan Powell'. 


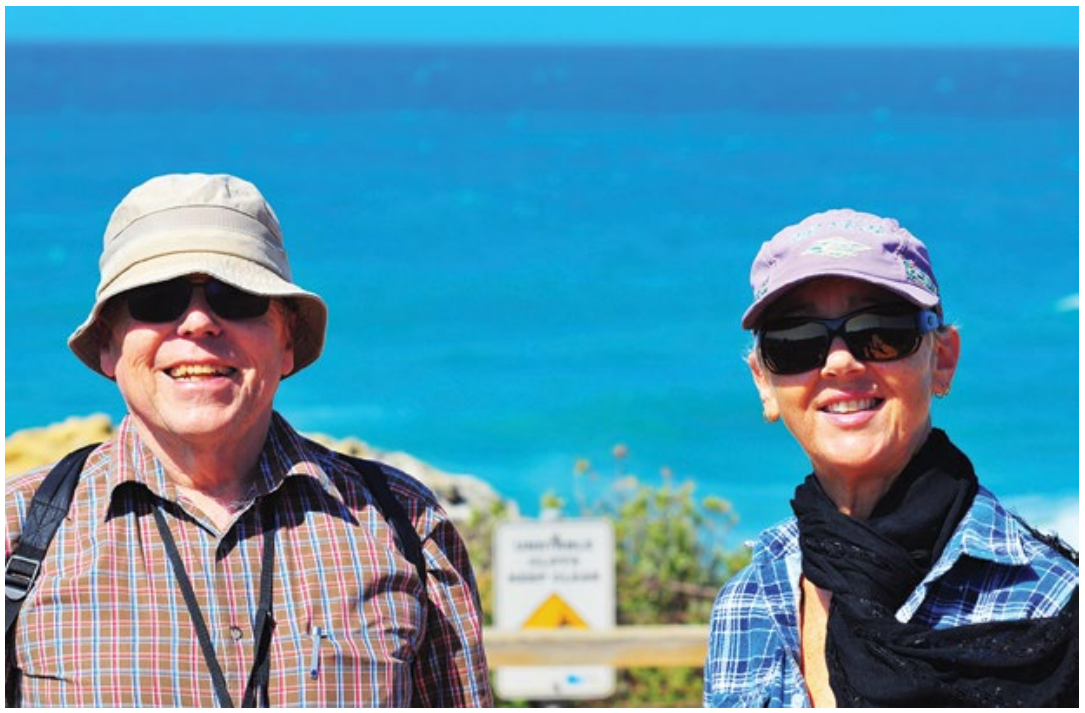

Figure 6: David Carment and Mickey Dewar at Aireys Inlet in 2015.

Source: David Ritchie.

\section{Books}

Mickey's many publications and reports, like other aspects of her activities, cover a multifaceted range of historical themes. These include Aborigines, cultural heritage management, crime and punishment, explorers, gender, identity, landscape, library services, literature, living conditions and lifestyles, museums, politics, race relations, sexuality and war. ${ }^{19}$ Almost all are also found in the five most substantial of her sole-authored books.

The Australian National University's North Australia Research Unit published Mickey's first major book, The 'Black War' in Arnhem Land: Missionaries and the Yolngu 1908-1940, in 1992. Unlike the broader prize-winning Master's thesis from which it is derived, the focus is on the Caledon Bay and Woodah Island incidents of the early 1930s in which Yolngu people killed non-Aborigines. Based on extensive primary sources that include church and government archival records as well as a key participant's private papers and recollections, the book tells an intriguing story.

19 Dewar, Resumé, 3-7. 


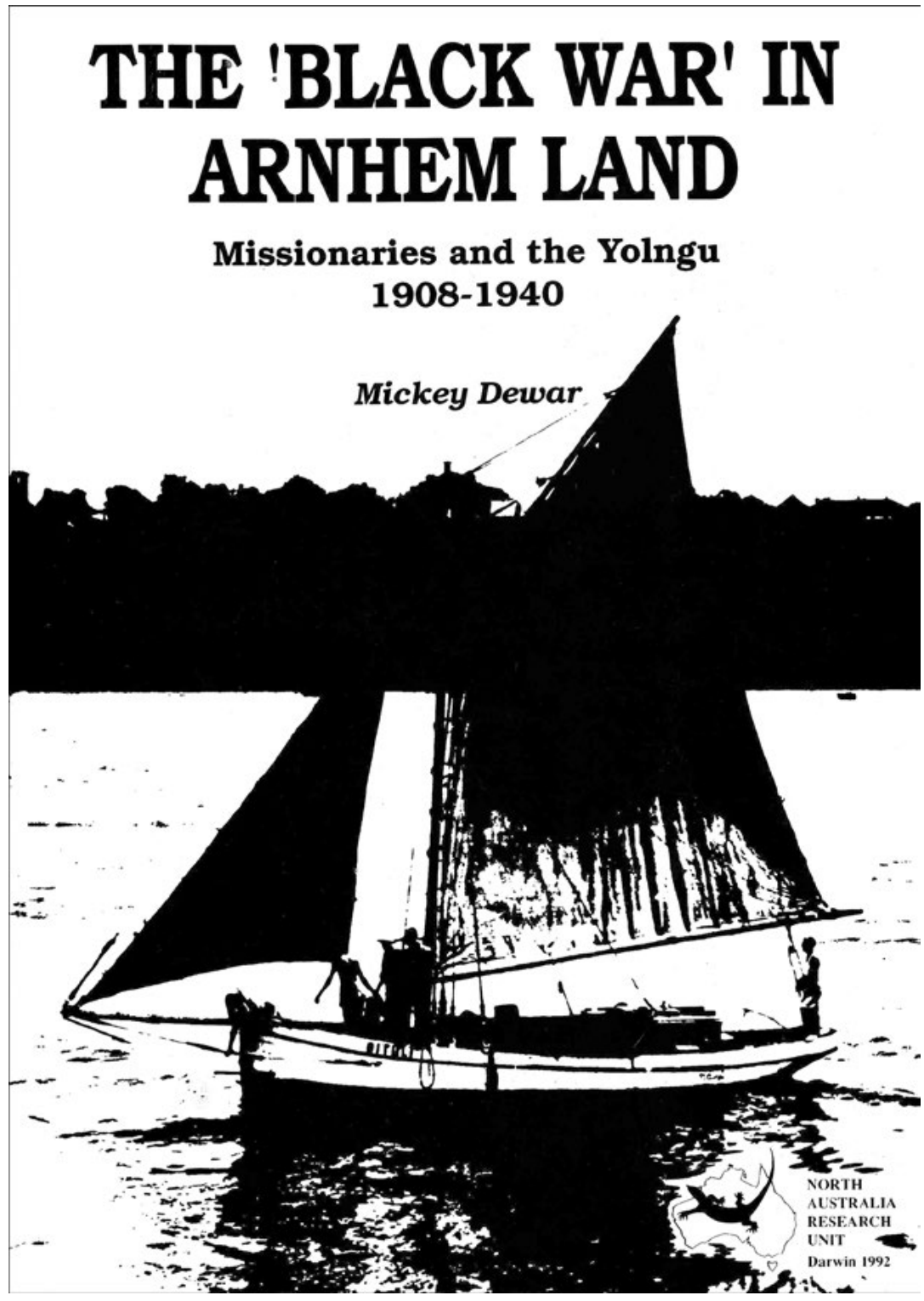

Figure 7: Mickey Dewar, The 'Black War' in Arnhem Land: Missionaries and the Yolngu 1908-1940 (Darwin: North Australia Research Unit, 1992).

Source: The Australian National University and David Ritchie. 
Commonwealth Government policy and missionary activities in Arnhem Land are examined in the wider context of developing Australian racial attitudes. Mickey shows that by the early twentieth century, Anglican and Methodist missionaries in the region had established settlements from which they created an enduring network. The Commonwealth Government was keen for economic reasons to leave Arnhem Land's administration to them. Throughout the 1920s, however, the killings of Japanese trepang crews by Yolngu and allegations of missionary misconduct established Arnhem Land as a wild frontier in the minds of many white Australians. Mickey constructs a detailed and perceptive forensic analysis of how further Yolngu murders of Japanese trepang fishermen at Caledon Bay in 1932 and white men at Woodah Island in 1933, probably as retribution for sexual interference with Yolngu women, resulted in a 'Peace Expedition' led by missionaries that brought the bewildered offenders into Darwin for trials they did not understand. While this was happening, Aboriginal rights to justice and land were increasingly debated. ${ }^{20}$ Mickey concludes that the 'dramatic events in Arnhem Land ... which were perceived as the struggle by Aborigines to exercise rights over country, laws and beliefs, became the catalyst for the consciences of white Australians'. ${ }^{21}$

Mickey's next substantial work was Beginnings: The First Decade of the Northern Territory Women's Advisory Council 1983-1993, published as a commissioned history in 1994. A significant contribution to regional studies of women's organisations, it makes considerable use of the numerous interviews that she undertook. She was 'totally disarmed by the candid and friendly way that people spoke to me', ${ }^{22}$ but perhaps ought not have been given her formidable skills as an oral historian.

Beginnings closely examines how the Women's Advisory Council (WAC) influenced Northern Territory Government decision-making. It explains that despite gains made during the 1960s and 1970s Northern Territory women, as in the rest of Australia, had not achieved equality with men in most key areas by the early 1980s. Mickey presents WAC's first 10 years as:

20 Dewar, The 'Black War' in Arnhem Land.

21 Dewar, The 'Black War' in Arnhem Land, 87.

22 Dewar, Beginnings, 7. 
The transition period from marginalised lobby group to incorporation within the mainstream political process. The ten years of WAC's operation have in large part been taken up with defining roles, establishing parameters of influence and generally working out ways to work effectively for women. ${ }^{23}$

She acknowledges that the council was confronted with a range of obstacles and experienced difficult times, yet also demonstrates that it lobbied successfully for improvements regarding such issues as discrimination against women, the protection of female victims of domestic and sexual violence, and the needs of female child care workers. WAC's advocacy, public education and networking activities are described and critically assessed. Of special interest is her attention to its deliberate consciousness ranging, which often concerned topics that had previously received little or no attention in the Northern Territory. ${ }^{24}$

Northern Territory University Press published Mickey's In Search of the Never-Never: Looking for Australia in Northern Territory Writing in 1997. It won the Jessie Litchfield Award for Literature and was shortlisted for the Community and Regional History Prize in the New South Wales Premier's History Awards. ${ }^{25}$ Based on her doctoral thesis, it analyses hundreds of fiction and non-fiction books and pamphlets published between 1837 and 1992. 'After reading all I could about the Territory', Mickey writes:

I came to believe that the focus of the region in the writing was an attempt to locate and define the non-Aboriginal occupation of Australia from all aspects: physically, spatially, morally and temporally. Northern Territory writing offers an interpretation of the settlement of Australia which seeks to legitimise European settlement. Representations of the Northern Territory can be seen to have developed and modified in response to changing events in Australian society generally. The Northern Territory as metaphor in Australian writing is the microcosm where the European occupation of the continent is reconciled. ${ }^{26}$

She sees landscape, Aboriginal people and gender as the Territory's principal literary representations. The common theme of the 'conflicting demands of European settlement against the rights of Aboriginal people' is

23 Dewar, Beginnings, 10.

24 Dewar, Beginnings, 9-77.

25 Dewar, Resumé, 2.

26 Dewar, In Search of the Never-Never, ix-x. 
found, although in varying degrees, in all the publications she examines. ${ }^{27}$ The idea of the frontier and the Territory's identity as being in some ways Asian are also of considerable importance.

Each of her eight chapters deals with a historical period but, as chapter titles such as 'Looking for Gold', 'The Atomic Territory' and 'Poor Bugger All of Us' reveal, also focus on particular issues. In 'The Atomic Territory', for instance, Mickey considers the years between the late 1940s and the early 1970s. During this period, the 'mythic theme' that the Territory's landscape contained unlimited wealth was 'buoyed by hopes of the atomic age'. ${ }^{28}$ Yet while 'economic optimism and iconic nationalism unite in the same landscape, ${ }^{29}$ writers such as Sumner Locke-Elliot and Bill Harney often present a more complicated perspective. ${ }^{30}$ Mickey's final chapter concludes that the majority of her authors throughout the 1837-1992 period amalgamated 'the landscape, the politics and the personal' in their attempts to identify the true Australia in their writings about the Territory. ${ }^{31}$

I have a closer personal connection with In Search of the Never-Never than any of Mickey's other sole-authored books. Not only is it based on the thesis that Alan Powell and I supervised, but I was also involved with its publication process and it strongly influenced some of my later research and writing. Alan, the examiners and I all considered that the thesis was an innovative and significant contribution to Australian cultural history that ought to be published. My only regret, which Mickey shared, is that following an independent referee's recommendations some of the biographical details in the thesis are omitted from the book. As chair of Northern Territory University Press, I successfully applied for a grant from the Australia Foundation for Culture and the Humanities that funded professional copyediting and indexing, and the inclusion of high-quality colour images. My own 2007 book Territorianism: Politics \& Identity in Australia's Northern Territory 1978-2001 acknowledges In Search of the Never-Never's importance in shaping its arguments, especially those regarding the Northern Territory as an Australian frontier and the relationship between the Territory and Asia. ${ }^{32}$

27 Dewar, In Search of the Never-Never, xii.

28 Dewar, In Search of the Never-Never, 111-12.

29 Dewar, In Search of the Never-Never, 112.

30 Dewar, In Search of the Never-Never, 95-117.

31 Dewar, In Search of the Never-Never, 191.

32 Carment, Territorianism, particularly viii, 7, 22-24. 


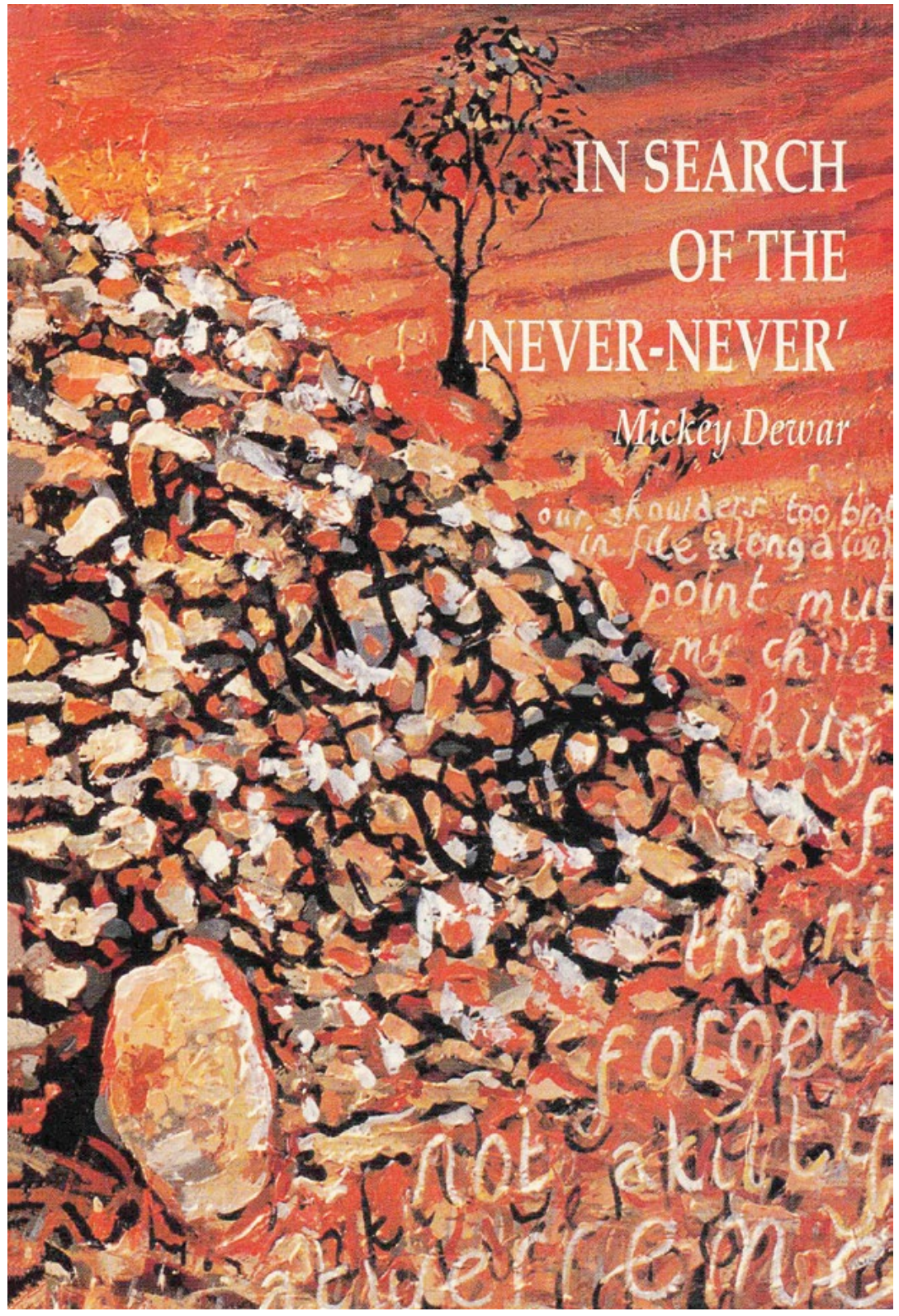

Figure 8: Mickey Dewar, In Search of the Never-Never: Looking for Australia in Northern Territory Writing (Darwin: Northern Territory University Press, 1997). Source: Charles Darwin University and David Ritchie. 
Inside-Out: A Social History of Fannie Bay Gaol, which Northern Territory University Press published in 1999, differs from most of Mickey's earlier books in not starting as a thesis. It is, instead, an outcome of her MAGNT curatorial activities. Like In Search of the Never-Never, it was shortlisted for the Community and Regional History Prize in the New South Wales Premier's History Awards. ${ }^{33}$ Most of the research was completed during her Northern Territory University Postdoctoral Fellowship. The gaol was Darwin's prison between 1883 and 1979. Although there were limitations regarding available evidence, especially the loss of all internal gaol documents, Mickey still found much relevant information from interviews, newspapers and government records. She observed that:

In its time the gaol housed political protesters, criminals, children, illegal aliens and people from all backgrounds and ethnic identities. Fannie Bay gaol was an institution which provided an intersection of race, class and authority. The gaol functioned as the chief place of incarceration for lawbreakers in the Northern Territory for ninety six years. As such, it provides a history, not only of the unfortunates who were incarcerated, the staff paid to supervise them, their families and friends and the victims of their crimes, but of the processes of settlement and control of the Northern Territory in the colonial and post-colonial period. ${ }^{34}$

The book's eight chronologically based chapters show how the gaol housed and dealt with people who in very various ways broke the law, as well as those who are often best seen as largely innocent offenders, such as a considerable proportion of the many Aboriginal and Chinese prisoners, children, the mentally ill and the poor. Some died of illness while imprisoned and others were executed. Most chapters give detailed and illuminating attention to the stories of individual prisoners: the Malay fisherman Joseph Abdoolah, who could not or would not settle into prison routines; the trade union leader Harold Nelson, imprisoned for refusing to pay taxes; the Aborigines Nemarluk and Butcher Knight, incarcerated for their involvement in killing non-Aboriginal people; the last prisoners hanged at the gaol, the Czechoslovaks Jerry Koci and John Novotny; the Portuguese seaman Jose $\mathrm{Da}$ Costa, whose death sentence was commuted very shortly before he was due to be executed; and the remand prisoner ' $L$ ', who was seriously assaulted by other prisoners. ${ }^{35}$ Mickey documents the gaol's serious deficiencies yet comments that its closure did not necessarily solve the Northern Territory's imprisonment problems. ${ }^{36}$ 


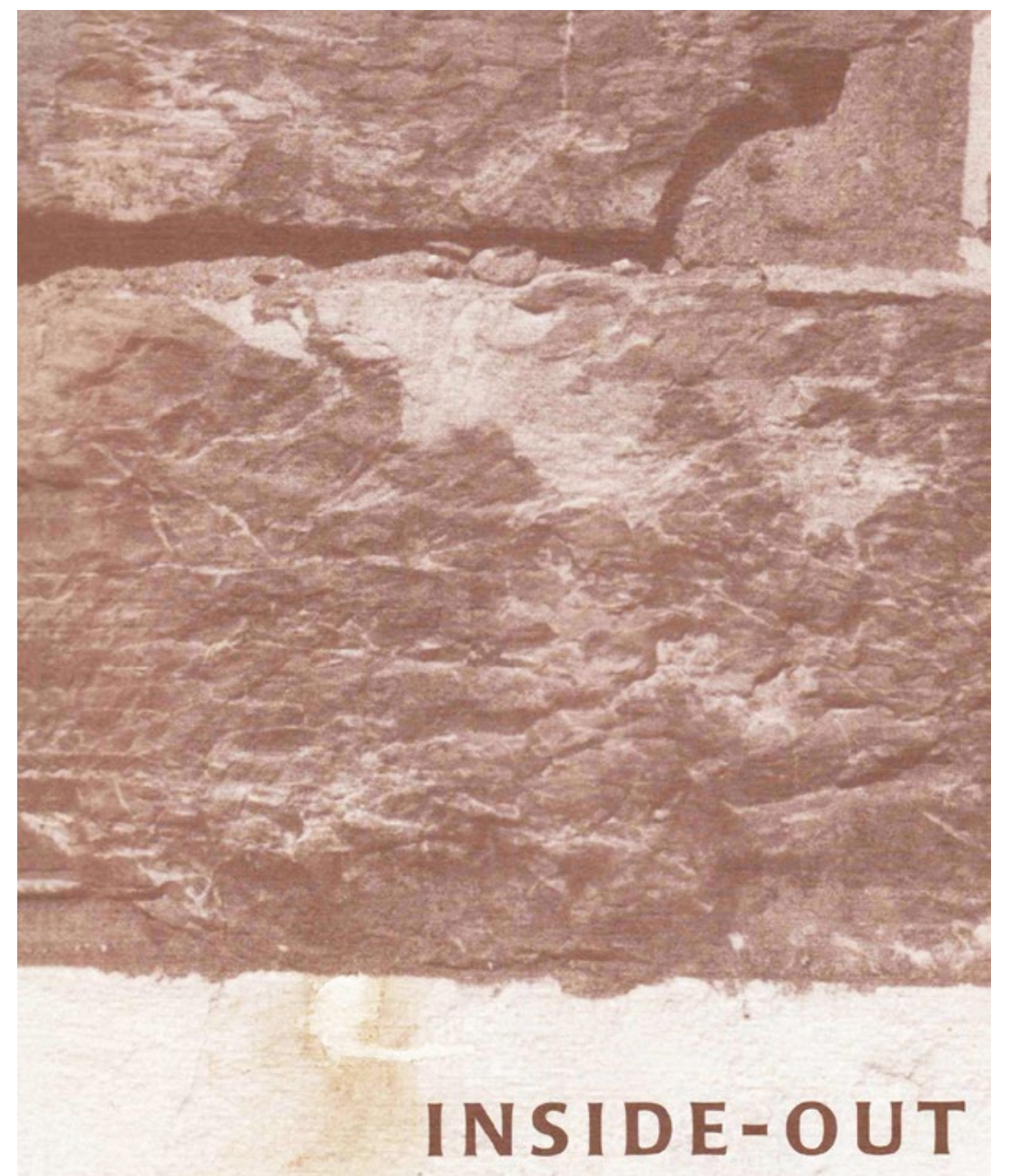

Mickey Dewar

Figure 9: Mickey Dewar, Inside-Out: A Social History of Fannie Bay Gaol (Darwin: Northern Territory University Press, 1999).

Source: Charles Darwin University and David Ritchie.

Mickey's last substantial book is Darwin - No Place Like Home: Australia's Northern Capital in the 1950s through a Social History of Housing, which the Historical Society of the Northern Territory published in 2010. She wrote it as a National Archives Frederick Watson Fellow and a Director's Fellow at the National Museum of Australia. It deservedly won the 
2011 Northern Territory Chief Minister's History Book Award. ${ }^{37}$ Like all Mickey's work, it is impeccably researched. The bibliography includes well over 100 National Archives of Australia and Northern Territory Archives files in addition to many oral history transcripts and other sources. Effective use is made of photographs and plans.

She employs this material to examine the challenges the Commonwealth Government faced during the 1950s as it attempted to rebuild Darwin following the Second World War's devastation and make it a place that its residents could call home. The book comprehensively discusses Darwin immediately after the Second World War, local politics, the Commonwealth's role as Darwin's principal landlord, life in the town's camps, the buildings where people lived, the Northern Territory Housing Commission's establishment and role, and architecture. She explains that, throughout the decade, land and accommodation remained insufficient. In spite of increased Commonwealth funds for housing, many people in Darwin found shelter where they could. In so doing they began to create communities that later emerged as suburbs. ${ }^{38}$ She writes that:

Having a house made the difference between staying and going. Despite (or perhaps because of) the tough conditions, Darwin people had a good time: they partied hard and drank vast quantities of alcohol, the weather was warm and the town was 'free and easy'. The local music scene arguably reached a creative height not matched again with a unique Darwin sound ... Along with the lifestyle came identification of a political attitude that was renegade, anti-Canberra, with an aggressive parochialism. ${ }^{39}$

Mickey argues that the demand for housing was the main point of political pressure in Darwin throughout the 1950s. Although the Commonwealth recognised and responded to the problem through increased expenditure and the Housing Commission's creation in 1959, its efforts 'entrenched the divide between public servants ... and the rest of the population' and set up a housing system that 'differentiated between Aborigines and other citizens'. ${ }^{40}$ More positively, the housing shortage forced a type of democracy on Darwin's citizens that subverted social hierarchies. 'What is really remembered as fundamental to the decade', Mickey notes, 'is the sharing of hardship and the creation of corporate entities of loyalty and political action'. ${ }^{41}$

37 Dewar, Resumé, 2.

38 Dewar, Darwin - No Place Like Home.

39 Dewar, Darwin - No Place Like Home, 5.

40 Dewar, Darwin - No Place Like Home, 6.

41 Dewar, Darwin - No Place Like Home, 141. 


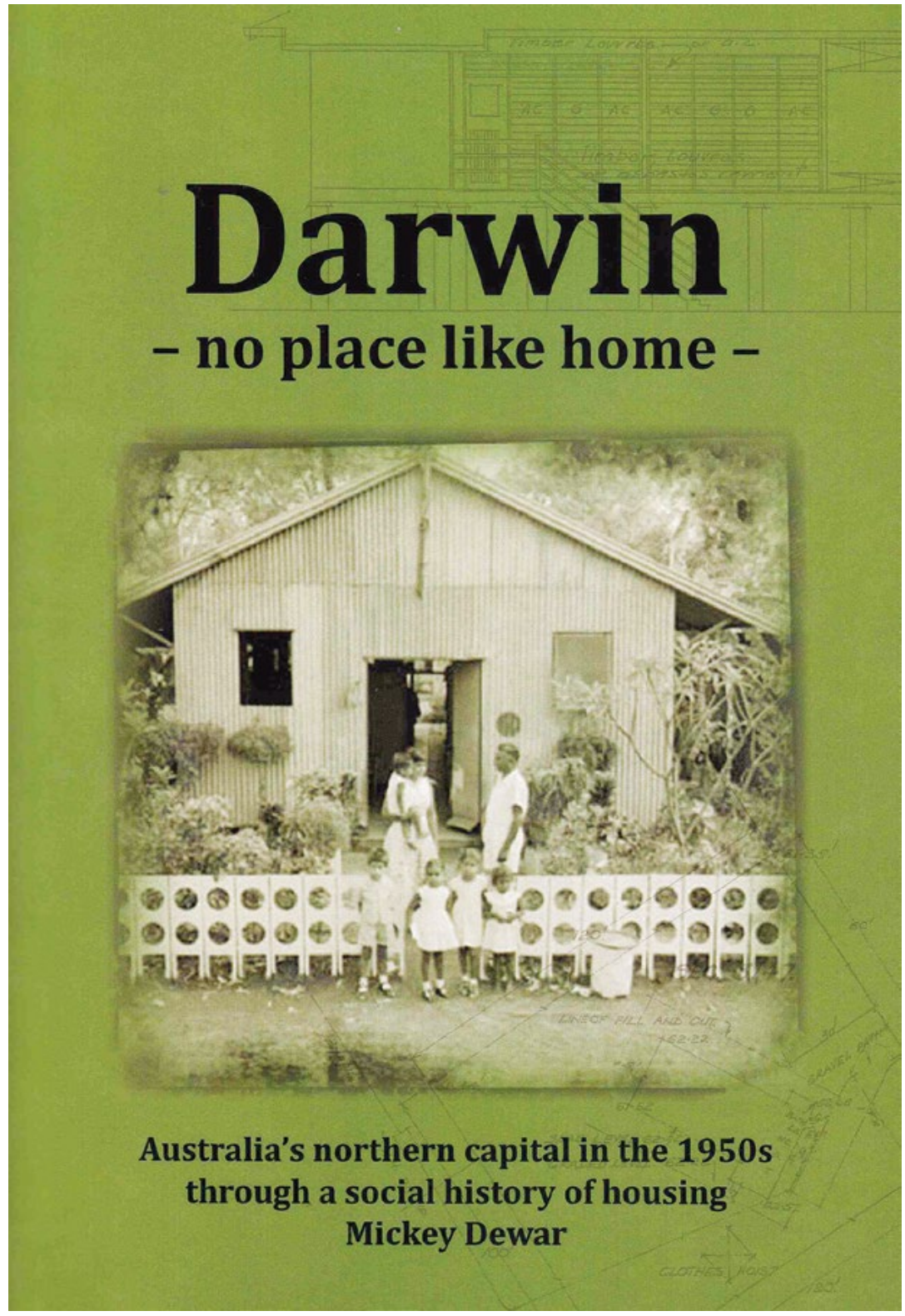

Figure 10: Mickey Dewar, Darwin - No Place Like Home: Australia's Northern Capital in the 1950s through a Social History of Housing (Darwin: Historical Society of the Northern Territory, 2010).

Source: Historical Society of the Northern Territory and David Ritchie. 


\section{Museums}

Most of Mickey's extensive curatorial work was at the MAGNT, a government organisation responsible for a number of sites. It was often accomplished in the face of difficulties. Until the Country Liberal Party lost office in 2001, the Territory Government sometimes intervened in the museum's operations and reduced its autonomy. ${ }^{42}$ Despite this, Mickey remained admirably loyal to the institution and successfully focused on a range of creative initiatives. She wrote conservation and management plans for MAGNT properties in Alice Springs and Darwin and authored scholarly publications dealing with aspects of her museum work. Exhibitions and sites for which she was largely responsible, examples of which are discussed here, were acclaimed for the innovative and thorough ways in which they presented history to diverse audiences. That they were often undertaken with limited resources makes them all the more noteworthy.

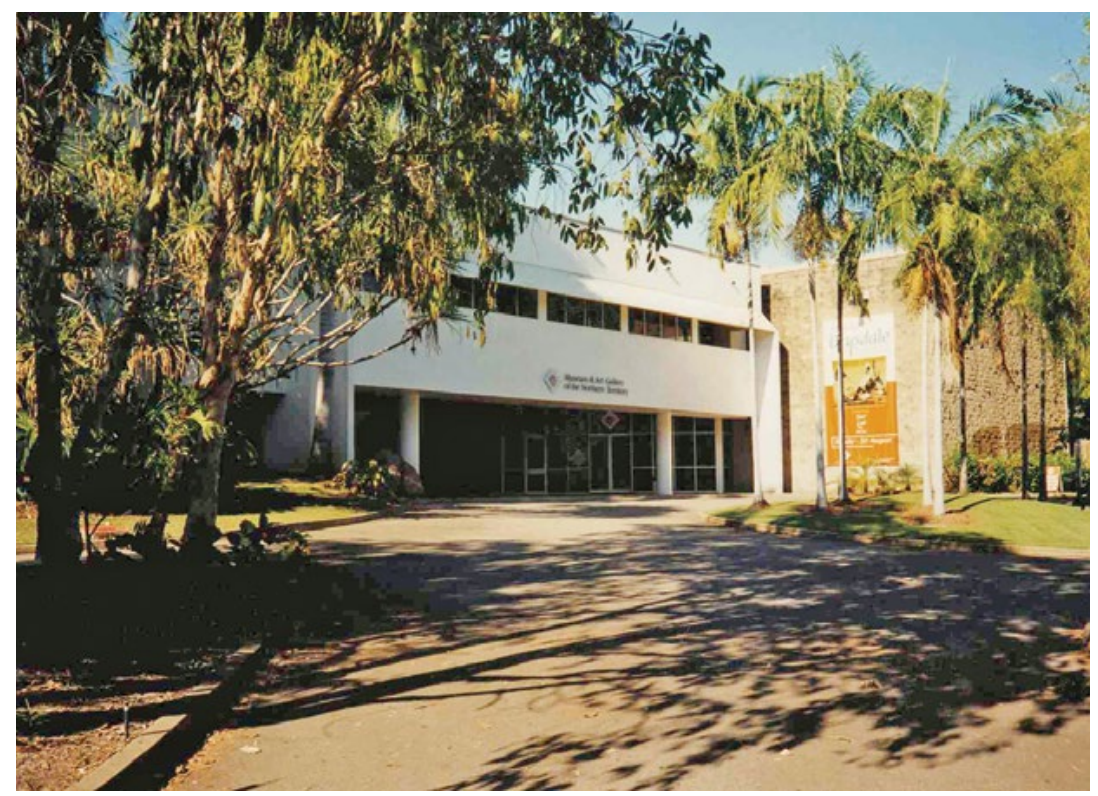

Figure 11: Museum and Art Gallery of the Northern Territory, Bullocky Point, Darwin, in 1998.

Source: David Carment.

42 Carment, 'Making Museum History in Australia's Northern Territory', 164-65. 


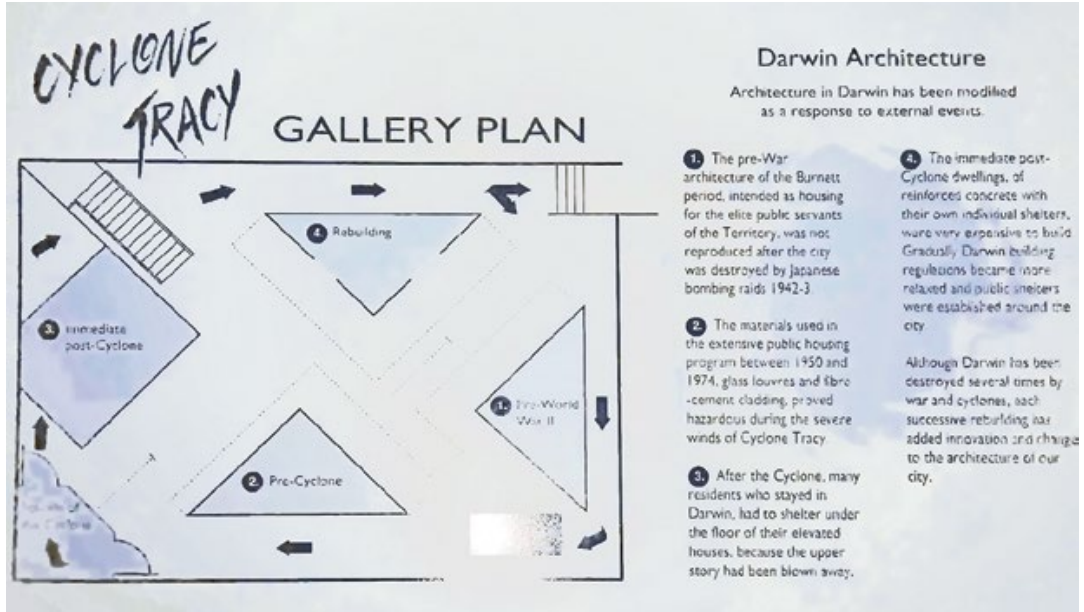

Figure 12: Gallery Plan, ‘Cyclone Tracy’ exhibition, in 1998.

Source: David Carment, photograph taken with the permission of the Museum and Art Gallery of the Northern Territory.

In the Cyclone Tracy Gallery, as it was officially described, Mickey documented the disaster that destroyed most of Darwin on 24 and 25 December 1974. It opened in 1994. As Peter Read shows in his book Returning to Nothing: The Meaning of Lost Places, it was part of controversial twentieth anniversary commemorations that raised the question of whether the cyclone ought to be celebrated or mourned. Read writes that Mickey wanted visitors:

to understand the different phases of Darwin's history, to make connections between the sites of 1974 and 1994, and to take cyclones seriously. Even the decision to begin was controversial: half the people who contacted her advised Don't do it: leave the past where it was. Dewar replied: These events will always be remembered but it is how we remember them that gives meaning to the present. ${ }^{43}$ 


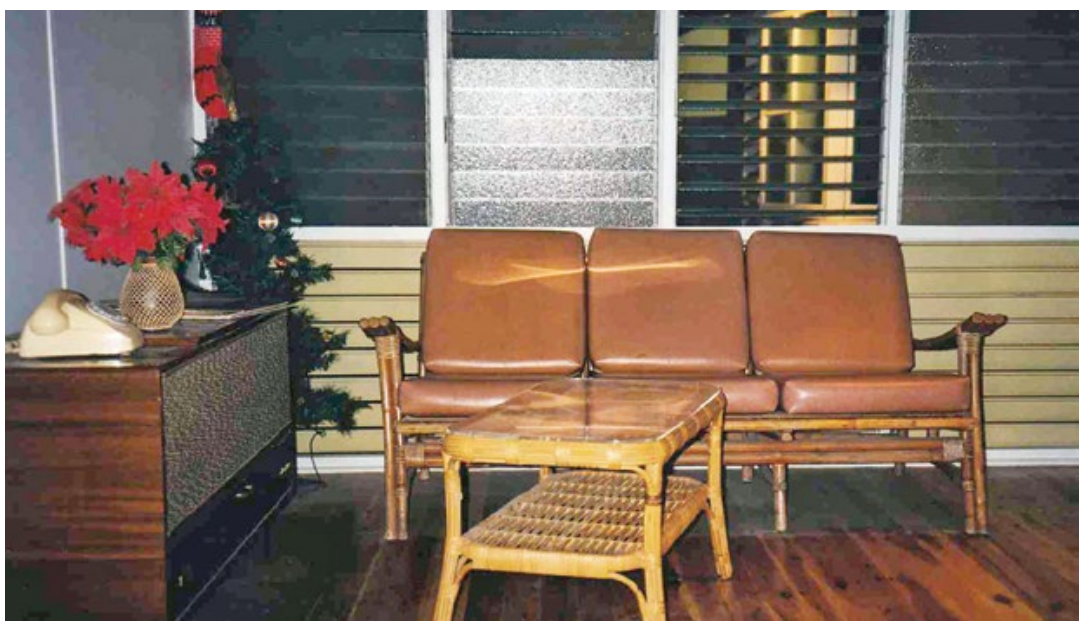

Figure 13: Pre-cyclone house, 'Cyclone Tracy' exhibition, in 1998.

Source: David Carment, photograph taken with the permission of the Museum and Art Gallery of the Northern Territory.

The exhibition, most of which is still in place, was highly effective and extraordinarily popular. In 1996-97, for example, over 168,000 people were estimated to have seen it. ${ }^{44}$ Visitors initially encountered Aboriginal artistic responses from Geoffrey Mangalamarra and Rover Thomas. They then inspected photographs of the cyclone's impact and viewed an $\mathrm{ABC}$ television report made not long after the disaster. They walked past skilful recreations of houses and rooms that were typical of Darwin in the precyclone period before entering what Read describes as the 'technological masterpiece'. A haunting recording of the cyclone made towards the end of midnight mass in Darwin's Catholic cathedral played continuously in a darkened room. As visitors left the room, they saw the wrecked remains of a high-set house, complete with a fallen Christmas tree. A large, hastily painted sign on a piece of iron warned, 'KEEP OUT WE STILL LIVE HERE'. From there the new post-cyclone Darwin was discovered, perhaps most notably part of the interior of a very solid 'Tracy Trauma' house of the type common in Darwin's northern suburbs. Darwin's people were shown rebuilding their community. ${ }^{45}$

44 Museums and Art Galleries Board of the Northern Territory, Annual Report 1996-97, 62.

45 Carment, notes and photographs of visit to Museum and Art Gallery of the Northern Territory, Darwin, 1998; Read, Returning to Nothing, 168-69. 


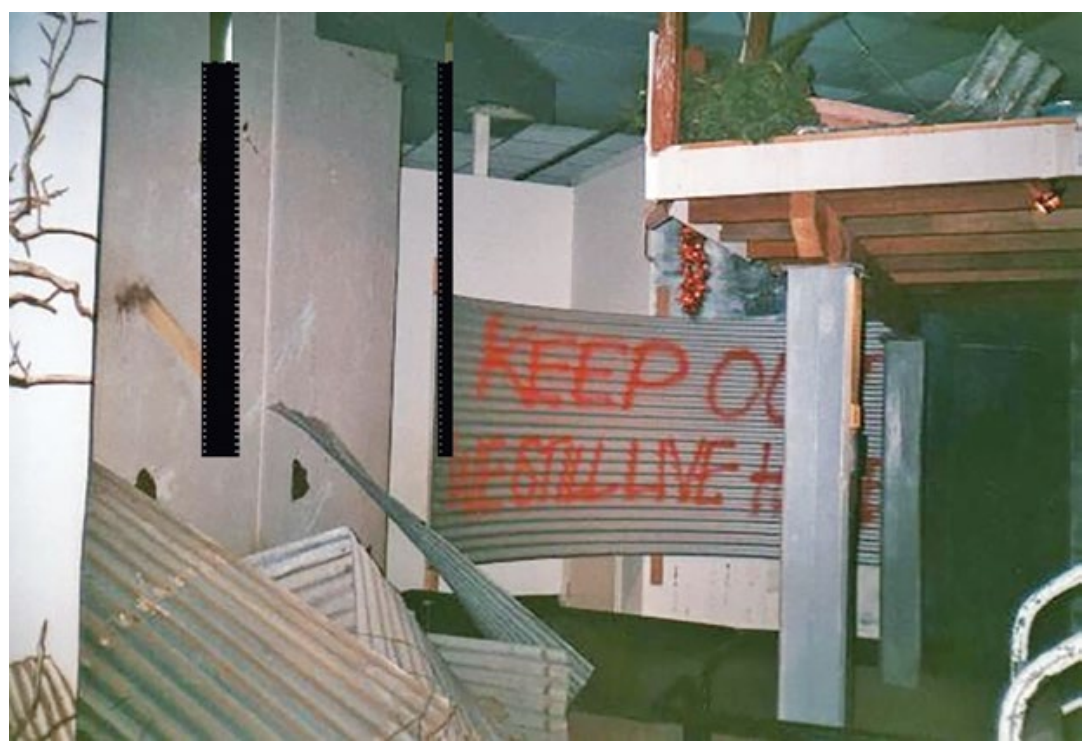

Figure 14: Cyclone damage, 'Cyclone Tracy’ exhibition, in 1998.

Source: David Carment, photograph taken with the permission of the Museum and Art Gallery of the Northern Territory.

Mickey's interpretation strategy for the former Fannie Bay Gaol in Darwin, based on a 1994 draft management plan, was to ensure that all buildings were conserved in accordance with recognised conservation principles and presented to demonstrate the nearly intact features of a medium-security tropical prison. ${ }^{46}$ Research for Inside-Out provided comprehensive interpretation material that included building histories and biographies of better-known prisoners. Mickey also worked with Clayton Fredericksen from Charles Darwin University on aspects of the gaol's archaeology that illuminated the role of its many Chinese prisoners. ${ }^{47}$ The buildings varied greatly: some were constructed in the late nineteenth century, while others were much more recent. Except for the removal of a few portable structures, no attempt was made to alter the gaol as it was in $1979 .{ }^{48}$

46 Dewar, 'Fannie Bay Gaol'.

47 Dewar and Fredericksen, 'Prison Heritage, Public History and Archaeology at Fannie Bay Gaol, Northern Australia'.

48 Carment, notes and photographs of visit to Fannie Bay Gaol, Darwin, 1998; [Dewar], Fannie Bay Gaol. 


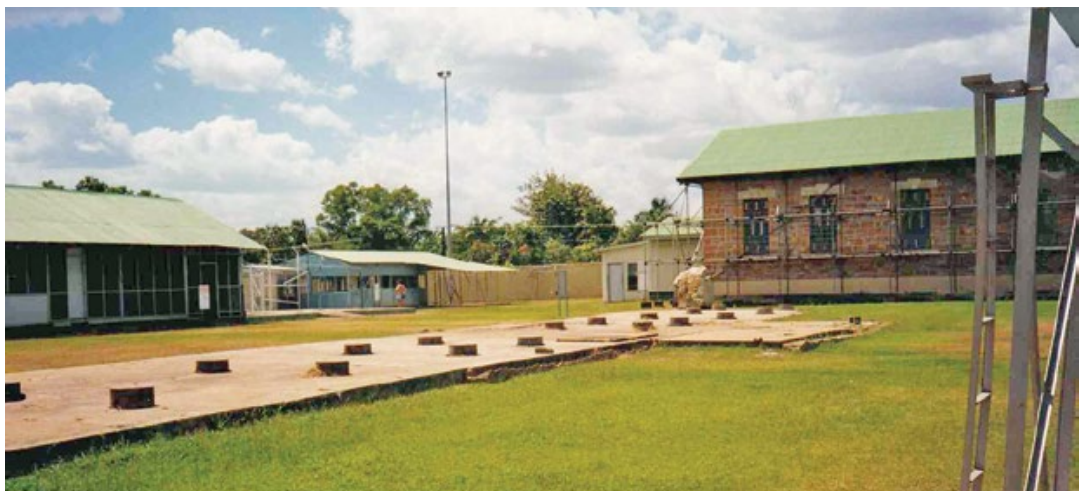

Figure 15: Fannie Bay Gaol in 1998.

Source: David Carment, photograph taken with the permission of the Museum and Art Gallery of the Northern Territory.

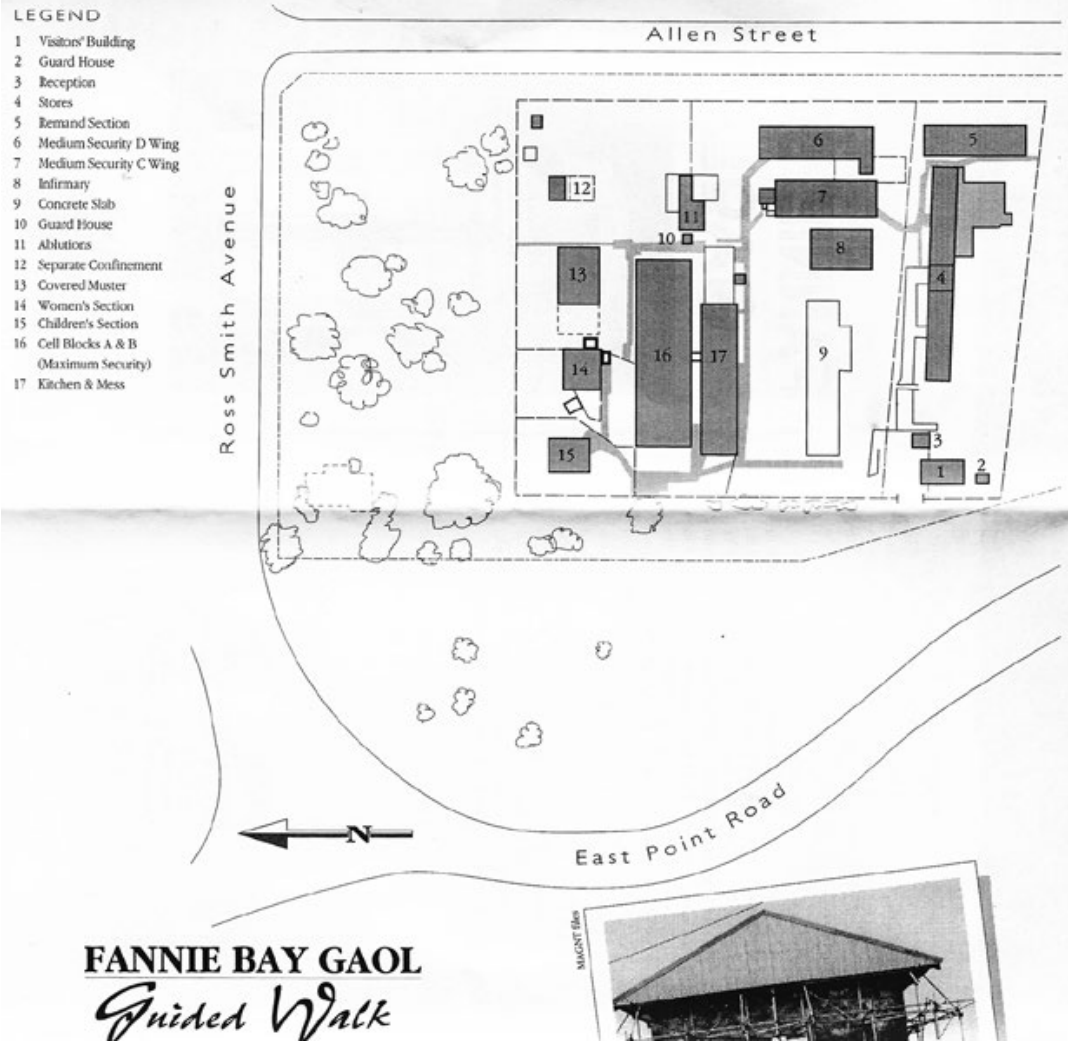

Figure 16: [Mickey Dewar 1995], Fannie Bay Gaol, Museums and Art Galleries of the Northern Territory, Darwin.

Source: Image courtesy Museum and Art Gallery of the Northern Territory. 
A guided walk at the gaol presented stories of the places visitors saw: the visitors' building, the guard house, the reception areas, the stores, the remand section, the maximum security cells, the infirmary, a concrete slab, the guard house, the ablution block, the separate confinement area, the covered muster area, the women's section, the kitchen and the mess. Visitors were asked to imagine what it was like to be a prisoner at the gaol over a century before when many inmates were Malay, Chinese or Aboriginal. ${ }^{49}$

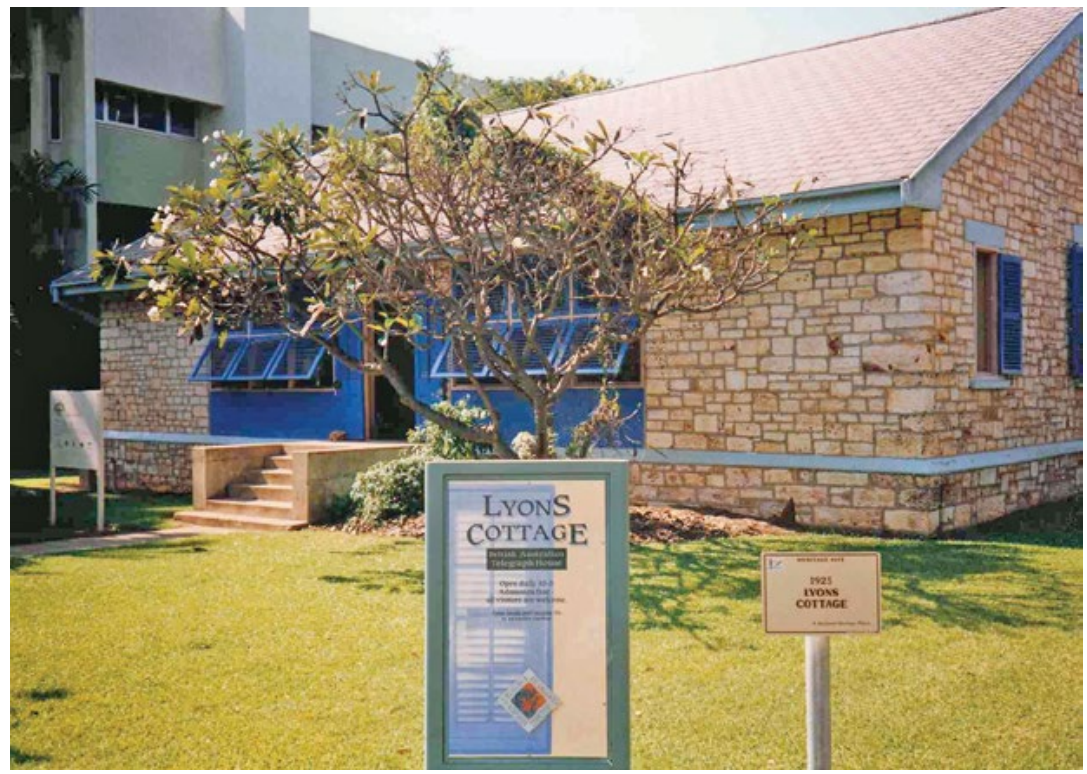

Figure 17: Lyons Cottage, Darwin, in 1998.

Source: David Carment.

Another of Mickey's Darwin projects was Lyons Cottage, also known as British Australian Telegraph House. Located on The Esplanade, it was a stone cottage built in 1925 as accommodation for staff maintaining the cable link between Australia and Britain. It was later the home of John Lyons, a prominent lawyer and mayor of Darwin, and his family. Under a draft management plan Mickey developed during the mid-1990s in collaboration with heritage professionals and long-time Darwin residents, the MAGNT restored the building. Its exterior reflected the colour scheme of the period from 1949 until 1970 while the interior reflected the

49 [Dewar], Fannie Bay Gaol. 
period from 1925 until 1942. Housed inside the cottage were displays of telegraphic equipment and photographs depicting local lifestyles. Visitors received a pamphlet outlining the building's history. ${ }^{50}$

Mickey was also responsible for The Residency, a MAGNT property in Alice Springs. The home of the Government Resident of Central Australia between 1927 and 1931, after then it housed senior officials. It was the scene for social gatherings, meetings and vice-regal occasions. Under Mickey's supervision in 1994, the MAGNT formulated a conservation plan and began work on the building to present aspects of its social history. Care was taken not to destroy evidence of any period but to keep examples of all stages of the building's use. ${ }^{51}$ As Mickey colourfully recounts in her article 'Attitudes to the Throne: Loyalty and Royalty at The Residency, Alice Springs', following consultation with the Alice Springs community the toilets installed for the visit of Queen Elizabeth II and the Duke of Edinburgh in 1963 were retained as a significant part of the building's history. ${ }^{52}$ The colour scheme chosen matched paint scrapings from the original design and the furniture was based on lists in government records. Interpretive texts were minimal, allowing visitors to experience the building's atmosphere. ${ }^{53}$

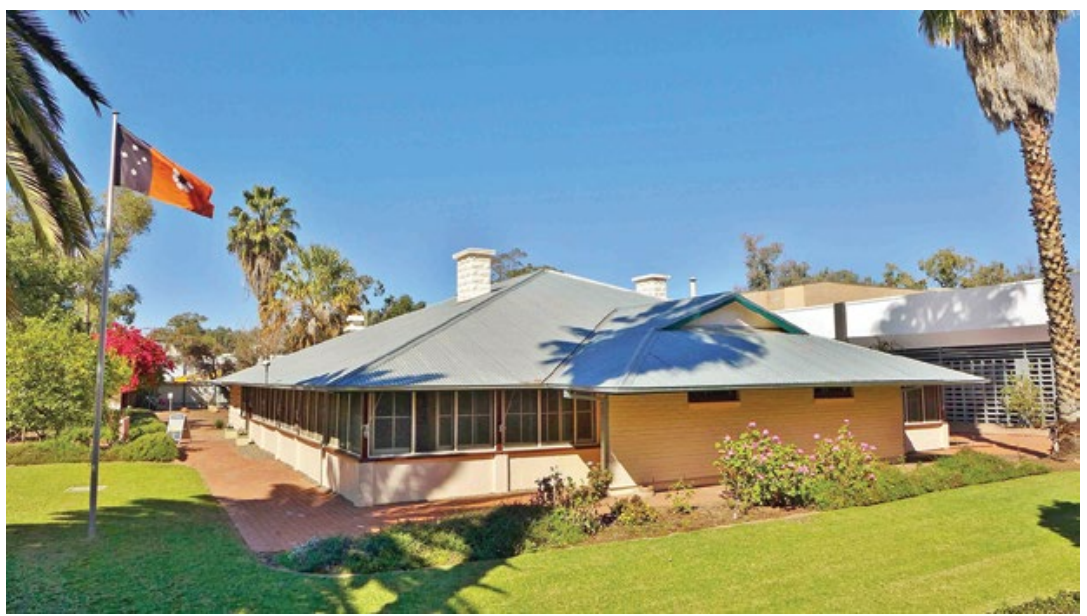

Figure 18: The Residency, Alice Springs, in 2015.

Source: Wikipedia Commons.

50 Carment, notes and photographs of visit to Lyons Cottage, Darwin, 1998; [Dewar], Lyons Cottage.

51 Dewar, The Residency Alice Springs Draft Report; [Dewar], The Residency Alice Springs.

52 Dewar, 'Attitudes To The Throne'.

53 Carment, notes and photographs of visit to The Residency, Alice Springs, 1998. 


\title{
Attitudes To The Throne: Royalty And Loyalty At The Residency, Alice Springs ${ }^{1}$
}

\author{
Mickey Dewar
}

As we approach the centenary of Federation, the republican debate heats up. For a historian, it is always interesting to look at such expressions of popular sentiment in context, both national and regional. Commentators have generally assumed that enthusiasm for royal tours has been steadily waning since the heady days of the 'enthusiastic scenes' of $1954^{2}$ where the 'queen had made a reality the long-planned tour that was to bring the millions of her antipodean peoples into more intimate unity with the crown' ${ }^{3}$ The Royal tour did take on a new lease of life in 1983 when the Prince and Princess of Wales visited Australia, although ten years on, the growing republican debate both here and in Great Britain, suggests that the pendulum has swung the other way again. But ascertaining popular attitudes can be a difficult task and we are largely dependent upon the media. As Richard Walsh pointed out,

\begin{abstract}
How successful the 1963 Australian Tour was is a matter for conjecture. The interpretation offered by the Australian Press, as usual, depended solely on the line they were trying to peddle on the news-stands. ${ }^{4}$
\end{abstract}

Short of conducting daily polls, there are no ways of establishing Australian popular attitudes to the British monarchy. In the end, we are largely left, as our two key indicators for Australian attitudes to the monarchy, with press reports and the public enthusiasm for the republican debate.

Figure 19: Mickey Dewar, 'Attitudes to the Throne: Loyalty and Royalty at The Residency, Alice Springs', Northern Perspective 19, no. 1 (1996): 99.

Source: Charles Darwin University and David Ritchie.

Most rooms at The Residency were furnished as they would have been in the early years of its use. The dark wooden furniture in the dining room, for instance, was very typical of the 1930s. The kitchen was fairly primitive. The royal bathrooms were displayed as a 'permanent' record of the Queen's stay. An interpretive text in one of the bathrooms was headed 'The Royal thrones'. Structural changes to the buildings were seen in various places, including a fireplace that was bricked up with only some of the brickwork removed to display what was originally there. ${ }^{54}$

54 Carment, notes and photographs of visit to The Residency, Alice Springs, 1998. 


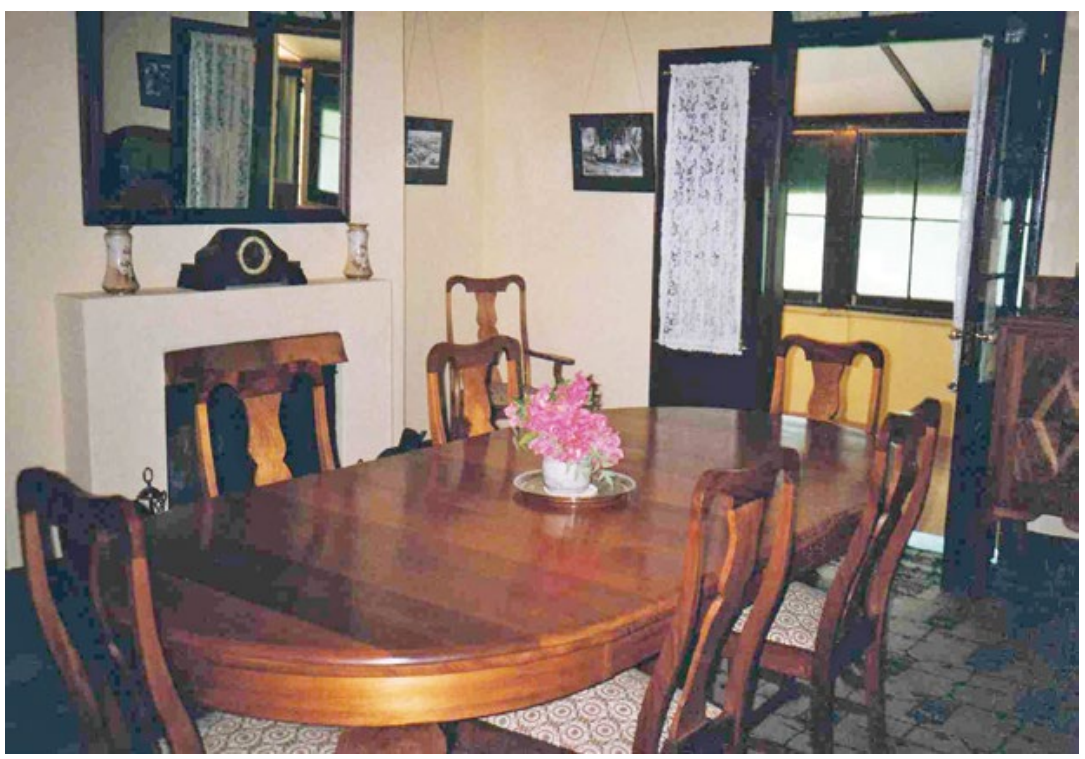

Figure 20: Dining room, The Residency, in 1998.

Source: David Carment, photograph taken with the permission of the Museum and Art Gallery of the Northern Territory.

As I mentioned earlier, Mickey returned to curatorship at the Northern Territory Library, where she worked from 2013. ${ }^{55}$ Her 2015 exhibition there, 'Borella's War', received an Australian Library and Information Association Northern Territory Recognition Award. ${ }^{56}$ The exhibition located the remarkable personal story of the Northern Territory's only First World War Victoria Cross winner, Albert Borella, within the broader context of Territory development. ${ }^{57}$ Mickey, though, also warned that while Borella's Territory and wartime experiences were valuable in illuminating the past, they 'were not typical ... the inevitable difficulty in any interpretations that focus on the heroic and the parochial is that they can also have the effect of distorting the public perception in a way not reflected in the wider events of the past'. ${ }^{58}$

\footnotetext{
55 Dewar, Resumé, 3.

56 Dewar, Resumé, 2.

57 'Borella's War: The Making of a Legend', 2015, World War One Link, accessed 24 August 2017, worldwaronelink.com.au/projects/borellas-war-making-legend/\#WajHkoVRzJx; Dewar, 'Borella's War'. 58 Dewar, 'Borella's War', 57.
} 


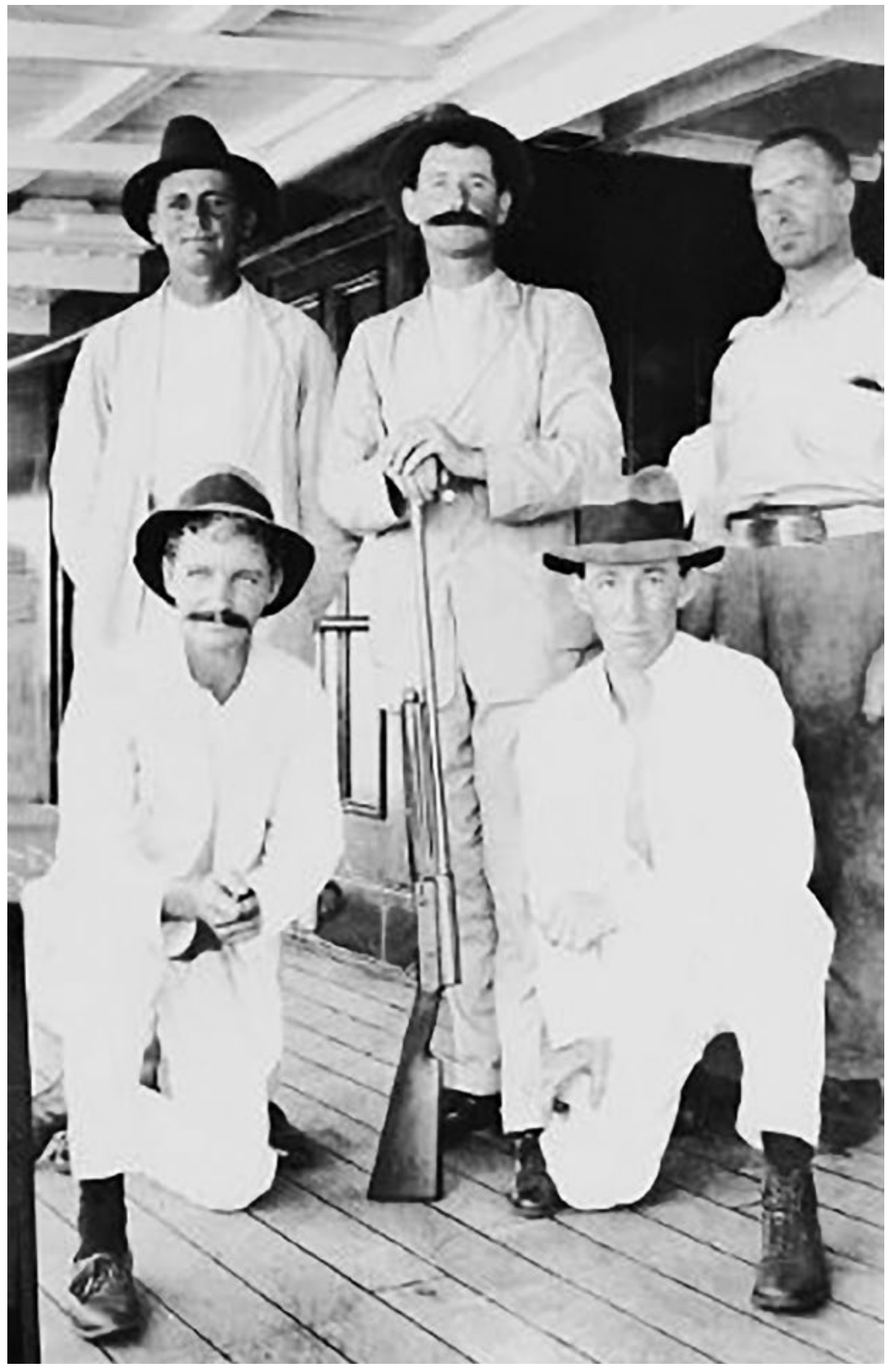

Figure 21: Image from 'Borella's War' exhibition, Northern Territory Library, 2015: sailing from Darwin to Townsville to enlist, Albert Borella is standing on the left.

Source: Northern Territory Library. 


\section{'Still so much to say'}

Mickey's resumé lists her passions as 'Northern Territory history, politics, knowledge information and retrieval, collections management, exhibition development, museums, libraries and archives'. ${ }^{59}$ She made valued, highly innovative and quite frequently pioneering contributions to all these areas. Ann McGrath wrote in 2004 that Mickey's career 'exemplifies the breadth of roles that a historian might play', referring to her curatorship, advice to the public on historical matters and publications. ${ }^{60}$ The Australian Historical Association's President Lynette Russell wrote shortly after Mickey's death that she was, among other things, 'in many ways an environmental historian before the label was used' ${ }^{61}$ As Clare Martin said at a farewell gathering in Darwin, Mickey is perhaps best remembered for being a wonderful storyteller who combined academic perspective and historical research with a 'regular dose of Dewar humour'. ${ }^{62}$ Mickey observed in one of her last emails to me that 'Northern Territory history is a subject I still love the best and think there is still so much to say' ${ }^{63}$ Her premature passing means that many stories will never be told.

\section{Bibliography}

Anderson, Margaret. 'Oh What a Tangled Web ... Politics, History and Museums'. Australian Historical Studies 33, no. 119 (2002): 179-85. doi. org/10.1080/10314610208596209.

Carment, David. 'Making Museum History in Australia's Northern Territory'. Australian Historical Studies 33, no. 119 (2002): 161-71. doi.org/10.1080/ 10314610208596207.

Carment, David. Territorianism: Politics \& Identity in Australia's Northern Territory 1978-2001. Melbourne: Australian Scholarly Publishing, 2007.

Carment, David, and Mickey Dewar. 'Darwin: Australia's Asian Capital?' Paper presented at Australian Historical Association Conference, Perth, 1994.

59 Dewar, Resumé, 2.

60 McGrath, 'The History Phoenix?', 15.

61 Russell, 'From the President', 325.

62 Manicaros, 'Friends and Colleagues Farewell Dr Mickey Dewar'.

63 Dewar, Email to David Carment, 10 February 2017. 
Carment, David, Clayton Fredericksen and Kathy De La Rue. 'From "Native Relics" to "Flynn's Pillar": Cultural Heritage Management in the Northern Territory during the 1950s'. In Modern Frontier: Aspects of the 1950s in Australia's Northern Territory, edited by Julie T. Wells, Mickey Dewar and Suzanne Parry, 91-102. Darwin: Charles Darwin University Press, 2005.

[Dewar, Mickey]. Lyons Cottage. Darwin: Museum and Art Gallery of the Northern Territory, n.d.

[Dewar, Mickey]. The Residency Alice Springs. Alice Springs: Museums and Art Galleries of the Northern Territory, n.d.

Dewar, Michelle [Mickey]. 'Strange Bedfellows: Europeans and Aborigines in Arnhem Land before World War II'. MA (Hons) thesis, University of New England, 1989.

Dewar, Mickey. The 'Black War' in Arnhem Land: Missionaries and the Yolngu 1908-1940. Darwin: North Australia Research Unit, 1992.

Dewar, Michelle Sue [Mickey]. 'In Search of the "Never-Never": The Northern Territory Metaphor in Australian Writing 1837-1992'. PhD thesis, Northern Territory University, 1993.

Dewar, Mickey. Beginnings: The First Decade of the Northern Territory Women's Advisory Council 1983-1993. Women's Advisory Council, Department of the thief Minister, Northern Territory Government, 1994.

Dewar, Mickey. 'Fannie Bay Gaol (Her Majesty's Gaol and Labour Prison, Darwin) Lot 5219'. Draft Heritage and Conservation management plan prepared by the Museum and Art Gallery of the Northern Territory, Darwin, 1994.

Dewar, Mickey. The Residency Alice Springs Draft Report. Museums and Art Galleries of the Northern Territory, Darwin, 1994.

[Dewar, Mickey]. Fannie Bay Gaol. Darwin: Museum and Art Galleries of the Northern Territory, 1995.

Dewar, Mickey. 'Attitudes To The Throne: Loyalty And Royalty At The Residency, Alice Springs'. Northern Perspective 19, no. 1 (1996): 99-111.

Dewar, Mickey. In Search of the Never-Never: Looking for Australia in Northern Territory Writing. Darwin: Northern Territory University Press, 1997.

Dewar, Mickey. Inside-Out: A Social History of Fannie Bay Gaol. Darwin: Northern Territory University Press, 1999. 
Dewar, Mickey. 'If I Was Writing My Own History I'd Be a Hero ... A Response to Professor David Carment on Making Museum History at the Museum and Art Gallery of the Northern Territory'. Australian Historical Studies 33, no. 119 (April 2002): 172-78. doi.org/10.1080/10314610208596208.

Dewar, Mickey. 'You Are What You Eat: Food and Cultural Identity'. In Modern Frontier: Aspects of the 1950s in Australia's Northern Territory, edited by Julie T. Wells, Mickey Dewar and Suzanne Parry, 71-90. Darwin: Charles Darwin University Press, 2005.

Dewar, Mickey. Darwin - No Place Like Home: Australia's northern capital in the 1950s through a social history of housing. Darwin: Historical Society of the Northern Territory, 2010.

Dewar, Mickey. 'Borella's War: The Making of a Legend'. Northern Territory Historical Studies: A Journal of History Heritage and Archaeology 27 (2016): 47-64.

Dewar, Mickey. 'Thoughts on Emeritus Professor Alan Powell'. Paper presented at Professor Alan Powell: Beyond the Far Country symposium, Darwin, 31 May 2017.

Dewar, Mickey, and Clayton Fredericksen. 'Prison Heritage, Public History and Archaeology at Fannie Bay Gaol, Northern Australia'. International Journal of Heritage Studies 9, no. 1 (2003): 45-63. doi.org/10.1080/13527250220 00056622 .

McGrath, Ann. 'The History Phoenix? Inventing a History Tradition in the Northern Territory'. In Northern Encounters: New Directions in North Australian History, edited by David Carment, 1-24. Darwin: Charles Darwin University Press, 2004.

Manicaros, Ashley. 'Friends and Colleagues Farewell Dr Mickey Dewar After Passing Away with Motor Neurone Disease'. Northern Territory News, 9 July 2017. Accessed 25 August 2017. www.ntnews.com.au/news/northern-territory/ friends-and-colleagues-farewell-dr-mickey-dewar-after-passing-away-frommotor-neurone-disease/news-story/0998c37e112410f22fba00c55a4d6883.

Martin, Clare, and Mickey Dewar (comps). Speak for Yourself: Eight Chief Ministers Reflect on Northern Territory Self-Government. Darwin: Charles Darwin University Press, 2012.

Museums and Art Galleries of the Northern Territory. Annual Report 1996-97. Darwin: The Board, 1997. 
IN SEARCH OF THE NEVER-NEVER

Powell, Alan. Far Country: A Short History of the Northern Territory. Melbourne: Melbourne University Press, 1983.

Read, Peter. Returning to Nothing: The Meaning of Lost Places. Melbourne: Cambridge University Press, 1996. doi.org/10.1017/CBO9781139085069.

Russell, Lynette. 'From the President'. History Australia 14, no. 3 (2017): 323-25. doi.org/10.1080/14490854.2017.1361785. 
This text is taken from In Search of the Never-Never: Mickey Dewar: Champion of History Across Many Genres, edited by Ann McGrath, published 2019 by ANU Press, The Australian National University,

Canberra, Australia.

doi.org/10.22459/ISNN.2019.04 